\title{
Splicing Factor 3B Subunit 1
}

National Cancer Institute

\section{Source}

National Cancer Institute. Splicing Factor 3B Subunit 1. NCI Thesaurus. Code C98286.

Splicing factor 3B subunit 1 (1304 aa, $146 \mathrm{kDa}$ ) is encoded by the human SF3B1 gene.

This protein is involved in the structure of the spliceosome. 